\title{
Susceptibility of the diamondback moth, Plutella xylostella (L) (Lepidoptera: Ypono- meutidae), to insecticide sprays on cabbage
}

\author{
Arrstides $M$. Arrnstrong
}

\begin{abstract}
Three field trials with cabbage var. Market Prize were established at the Isabela Substation, AES UPR, to evaluate the susceptibility of Plutella xylostella to various insecticides. Dosages recommended by the manufacfurer were used for the first two applications in the first trial, and some double dosages were included in an attempt to get at least a $90 \%$ control of the larvae population. For the other two trials, recommended dosages and the effective higher dosages from the first trial were compared. Significant differences were obtained with methamidophos $(2.34 \mathrm{U} / \mathrm{ha})$, permethrin ( 0.234 and $0.468 \mathrm{~L} / \mathrm{ha})$, and fenvalerate (0.35 U/ha) for controlling the larvae. Control figures for those four treatments were 97.8, 100, 100, and $99.9 \%$, respectively. Methamidophos, acephate, and naled controlled over $90 \%$ of the larvae only with double the recommended rates. Chlorpyrifos at $1.17 \mathrm{~L} / \mathrm{ha}$ was ineffective, but at its higher rate controlled 80 to $90 \%$ of the larvae. Diazinon, methomyl, dimethoate, and endosulfan even at their highest rates were ineffective for controlling the larvae. The number of larvae increased after each application of these insecticides. The greatest numbers of marketable heads were obtained from plots treated with permethrin, fenvalerate, and methamidophos at the highest rate for each.
\end{abstract}

\section{RESUMEN}

Susceptibilidad de la alevilla dorso de diamante, Plutella xylostella (L.) (Lepidoptera:Yponomeutidae), a los insecticidas aplicados al repollo en Puerto Rico

Se establecieron tres experimentos de campo con repollo, variedad Market Prize, en la Subestación de Isabela, UPR-EEA, para evaluar la resistencia de Plutella xylostella a varios insecticidas. En el primer ensayo se usaron las dosis recomendadas por el fabricante para las primeras dos aplicaciones y subsecuentemente se duplicaron para tratar de conseguir un $90 \%$ de control. En los otros dos ensayos se evaluaron las dosis recomendadas que fueron eficaces y las dosis dobles que también lo fueron en el primer ensayo. Se obtuvieron diferencias significativas con metamidofos (2.34 I./ha.), permetrina $(0.234$ y $0.468 \mathrm{l}$./ha.) y fenvalerato $(0.351 \mathrm{I} . / \mathrm{ha}$.) Los porcentajes de control obtenidos fueron $97.8,100,100$ y 99.9 , respectivamente. Metamidofos, acefato y naled reprimieron sobre el $90 \%$ de la larva solo cuando se utilizó el doble de la dosis recomendada. Clorpirifos a razón de 1.17 I./ha. fue ineficaz para combatir la larva, pero se obtuvo de 80 a $89 \%$ de mortandad cuando la dosis se duplicó. Diazinon, metomilo, dimetoato y endosulfan fueron ineficaces aun con dosis aumentadas. Las

'Manuscript submitted to Editorial Board 20 June 1989.

?Research Assistant in Entomology, Department of Crop Protection. 
larvas mostraron una tendencia a aumentar después de cada aplicación de estos insecticidas. El mayor número de repollos comerciales se obtuvo en las parcelas tratadas con permetrina, fenvalerato y metamidofos en sus dosis más altas.

\section{INTRODUCTION}

In 1986-87 Puerto Rico produced $65,000 \mathrm{cwt}$ of cabbage with a farm value of $\$ 500,000$ to 600,000 (11). This production is often seriously affected by the larvae of the diamondback moth, Plutella xylostella (L.) (7). Damage to cabbage is caused by the feeding of its small green larvae, which give the leaves a shot hole effect. The activity of a large number of larvae interferes with the healthy growth of the plants and considerably reduces yield (1).

Currently, application of foliar insecticides is the most common control method used by cabbage growers. During the 1970 s and early 80 s the UPR-AES evaluated the following insecticides for the effectiveness in controlling this insect: methamidophos $4 \mathrm{E}$, methomyl $1.8 \mathrm{~L}$, diazinon AG500, acephate $75 \mathrm{~S}$, permethrin $2 \mathrm{E}$, fenvalerate $2.4 \mathrm{E}$, and Bacillus thuringiensis var kurstaki (a biological insecticide) WP. Several of these insecticides that in first tests were effective in controlling the populations of the diamondback larvae did not control the pest effectively after being used for a few seasons. For example, when $P$. xylostella exhibited resistance to parathion and DDT in 1967 (7), the UPR-AES urged the use of diazinon as a substitute. In 1973, when field trials were conducted to evaluate diazinon AG500, methamidophos $4 \mathrm{E}$, and methomyl 90S, diazinon and methomyl showed poorly, whereas methamidophos was effective (8). The strong selection pressure caused by a constant use of diazinon from 1967 to 1973 was probably responsible for building resistance of $P$. xylostella to the chemical. In 1979, methomyl, methamidophos and acephate were evaluated; all were effective against the larvae (10). However, by 1980 these same insecticides were not as effective as in previous years (9). During that season, permethrin and fenvalerate effectively controlled the diamondback moth larvae (9). In the 1981-82 trials, the best control of $P$. xylostella larvae was obtained with permethrin (9). Thus, the general perception is that repeated use of the same insecticides has resulted in rendering several of them ineffective. The purpose of this study was to test some of the pesticides registered for cabbage and some new chemicals in order to evaluate the development of resistance of $P$. xylostella in the field.

\section{MATERIALS AND METHODS}

Three field trials with cabbage var. Market Prize were established at the Isabela Substation, UPR-AES. A complete randomized block design with three replications was employed for all three tests. The experimen- 
tal block consisted of three 10 -meter $\left(30^{\prime}\right)$ rows, spaced 1 meter $\left(3^{\prime}\right)$ apart with 0.5 meter $\left(1.5^{\prime}\right)$ between plants within rows. Yield data were collected in order to determine the economic impact. Marketable heads were those without damage to the leaves and with a weight between 1.8 to 2.3 $\mathrm{kg}$. In the first trial, dosages recommended by the manufacturer were used for the first two applications, and some dosages were then doubled for the next applications in an attempt to get at least a $90 \%$ control of the larvae population. For the other two trials, recommended dosages and the effective higher dosages from the first trial were used. To evaluate insecticide efficacy, we recorded one day before and 48 hours after each application the number of larvae in 10 plants per lot (10). Weekly sprays were initiated when 2.5 larvae per plant were present and the cabbage heads were beginning to develop.

In the first trial (14 December 1982 to 23 February 1983) the following insecticides were evaluated: methamidophos $4 \mathrm{E}$ at 1.17 and $2.34 \mathrm{~L} / \mathrm{ha}$ (1.0 and $2.0 \mathrm{pt} / \mathrm{acre})$, permethrin $2 \mathrm{E}$ at 0.234 and $0.468 \mathrm{~L} / \mathrm{ha}(0.2$ and 0.4 pt/acre), fenvalerate $2.4 \mathrm{E}$ at $0.351 \mathrm{~L} / \mathrm{ha}(0.3 \mathrm{pt} / \mathrm{acre})$, chlorpyrifos $4 \mathrm{EC}$ at $1.17 \mathrm{~L} / \mathrm{ha}$ (1.0 pt/acre), acephate $75 \mathrm{~S}$ at $0.672 \mathrm{~kg} / \mathrm{ha}(0.6 \mathrm{lb} / \mathrm{acre})$, methomyl $90 \mathrm{~S}$ at $0.6 \mathrm{~kg} / \mathrm{ha}(0.5 \mathrm{lb} / \mathrm{acre})$, diazinon AG500 at $1.17 \mathrm{~L} / \mathrm{ha}(1.0$ $\mathrm{pt} / \mathrm{acre})$, dimethoate $2.67 \mathrm{EC}$ at $1.17 \mathrm{~L} / \mathrm{ha}$ (1.0 pt/acre) and Bacillus thuringiensis var. kurstaki (B.t.) WP at $1.2 \mathrm{~kg} / \mathrm{ha}$ (1.0 lb/acre). The trial consisted of 12 treatments including the check. Five weekly insecticide applications were made. The first two (18 and 26 January 1983) were at the rates recommended by the manufacturers. For the following three applications (4, 9, and 16 February 1983) the rates were doubled except for permethrin, fenvalerate, and B.t. Nine readings of the larvae per plant and per plot were made.

The second trial (17 March to 26 May 1983) consisted of the same products as the first trial plus endosulfan 50WP at 0.6 and $1.2 \mathrm{~kg} / \mathrm{ha}(0.5$ and $1.0 \mathrm{lb} /$ acre) and naled $8 \mathrm{E}$ at 1.17 and $2.34 \mathrm{~L} / \mathrm{ha}$ (1.0 and $2.0 \mathrm{pt} / \mathrm{acre})$, for a total of 14 treatments including the check. Only the lowest recommended dosage for permethrin, fenvalerate, and B.t. was used. For all the other insecticides the recommended dosages were doubled. Two applications were made (2 May and 17 May 1983). Four readings of the number of larvae per plant were made.

In the third trial (15 December 1983 to 21 February 1984), insecticides diazinon, acephate, methamidophos, chlorpyrifos, naled, endosulfan, dimethoate, and methomyl were all evaluated at their highest recommended dosage for cabbage. Fenvalerate, permethrin, and B.t. were tested at the lower rate. There were 12 treatments including the check. Five weekly applications of the insecticides were made. The first was made 12 January and the last 8 February 1984. Larvae per plant per plot were counted 12 times. 


\section{RESULTS}

First trial

The statistical analysis of the data of this test showed significant differences for the recommended dosages for methamidophos $(2.34 \mathrm{~L} / \mathrm{ha})$, permethrin $(0.234$ and $0.468 \mathrm{~L} / \mathrm{ha})$, and fenvalerate $(0.351 \mathrm{~L} / \mathrm{ha})$ (table 1$)$. Control for those treatments was $97.8,100,100$, and $99.9 \%$, respectively. The analysis also showed that $88 \%$ control was obtained with methamidophos at the rate of $1.17 \mathrm{~L} / \mathrm{ha}$. However, the efficacy data obtained 48 hours and 6 days after each application show that methamidophos at $2.34 \mathrm{~L} / \mathrm{ha}$, permethrin at both rates, and fenvalerate were the only chemicals that consistently exerted over $90 \%$ control (table 2). Methamidophos at the $1.17 \mathrm{~L} /$ ha rate began with $87 \%$ control, but as the experiment progressed it lost some effectiveness to just above $50 \%$ control; only when the rate was doubled did it exert an effective control. Acephate proved to be fairly effective in controlling (77 to $92 \%$ ) the diamondback moth larvae (table 1) at the recommended rate with the first application, and nearly $100 \%$ effective with the next three applications at double the rate. With B.t. $(1.2 \mathrm{~kg} / \mathrm{ha})$ over $80 \%$ control of the larvae was obtained. Generally, this product proved to be very good in reducing the populations and keeping them at low levels (table 1). With weekly applications, after 2 to 3 applications, control could be more than $90 \%$.

The insecticides diazinon, chlorpyrifos, methomyl and dimethoate at the recommended rates were ineffective for controlling the diamondback larvae (table 1). Yields from the plots treated with these chemicals were not different from those of the check (table 3). The number of larvae in these plots increased after each application. This observation was made after the analysis of the percentage of reduction of the larvae $\{=[1-(\mathrm{No}$. of larvae post treated/No. of larvae pretreated) $\times 100]\}$ when the population of the pest within each plot (without comparing it with the check) after each application was compared (12).

The most marketable heads were obtained from the permethrin $(0.234$ $\mathrm{L} / \mathrm{ha}$ ), fenvalerate and methamidophos $(2.34 \mathrm{~L} / \mathrm{ha})$ plots; however, there were no significant yield differences among them. The number of marketable heads from the B.t. and acephate plots were not different from those of the permethrin $(0.468 \mathrm{~L} / \mathrm{ha}$ ) plots (table 3$)$. The highest yield (weight in $\mathrm{kg}$ ) was obtained with fenvalerate, followed by methamidophos (2.34 L/ha), permethrin (both rates), B.t. and acephate. No significant differences were found between the B.t. and acephate treatments.

\section{Second trial}

Only two applications of insecticides were made (2 and 17 May 1983). Four counts of the number of larvae per plant were taken (table 4). Rains during April and part of May limited the number of applications. The 
Taß31,F 1.-Experiment 1. Effectiveness of selected insecticides aguinst Plutella xylostella (L.) larvae on cubbage var, Market Prize (Isabela, P. R.-Dec. 1982-Feb. 1983)

\begin{tabular}{|c|c|c|c|c|c|c|}
\hline \multirow{3}{*}{$\begin{array}{c}\text { Treatment } \\
\text { (rate/hectare) }\end{array}$} & \multicolumn{3}{|c|}{ Recommended rate' } & \multicolumn{3}{|c|}{ Double the recommended rate: } \\
\hline & \multirow[b]{2}{*}{ Larvae/Plant" } & \multicolumn{2}{|c|}{ Percentages } & \multirow[b]{2}{*}{ Larvae/Plant: } & \multicolumn{2}{|c|}{ Percentatges } \\
\hline & & Control" & Reduction: & & Control: & Reduction: \\
\hline Methamidophos $4 \mathrm{E}$ (1.17 L/ha) & $4.83 \mathrm{bc}$ & 89 & 18 & $2.93 \mathrm{ab}$ & 64 & 56 \\
\hline Methamidophos $4 \mathrm{E}$ (2.34 L/ha) & $1.22 \mathrm{a}$ & 98 & 43 & $0.56 a$ & 91 & 59 \\
\hline Permethrin 2E $\quad(0.234 \mathrm{~L} / \mathrm{ha})$ & $0.53 \mathrm{a}$ & 100 & 89 & $0.00 \mathrm{a}$ & 96 & 100 \\
\hline Permethrin 2E & $0.56 a$ & 100 & 94 & $0.00 \mathrm{a}$ & 96 & 100 \\
\hline Fenvalerate $2.4 \mathrm{E} \quad(0.351 \mathrm{~L} / \mathrm{ha})$ & $0.63 \mathrm{a}$ & 100 & 95 & $0.02 \mathrm{a}$ & 95 & 100 \\
\hline Diazinon AG500 $\quad(1.17 \mathrm{~L} / \mathrm{ha})$ & $7.81 \mathrm{c}$ & 53 & -21.1 & $12.28 \mathrm{dc}$ & 41 & -1.9 \\
\hline Chlorpyrifos 4EC $\quad(1.17 \mathrm{~L} / \mathrm{ha})$ & $5.20 \mathrm{c}$ & 68 & -7.4 & $8.2 \mathrm{bc}$ & 61 & -41.4 \\
\hline Acephate $75 \mathrm{~S}$ & $2.48 \mathrm{ab}$ & 96 & 39 & $0.98 a$ & 81 & 55 \\
\hline Methomyl 90S & $13.37 \mathrm{~d}$ & 34 & -23.5 & $17.14 \mathrm{~d}$ & 1 & 49.5 \\
\hline Dimethoate $2.67 \mathrm{EC}$ (1.17 L/ha) & $7.06 \mathrm{c}$ & 45 & -8.2 & $14.43 \mathrm{dc}$ & 47 & -59 \\
\hline$(1.2 \mathrm{~kg} / \mathrm{ha})$ & $2.92 \mathrm{ab}$ & 88 & 43 & $3.18 \mathrm{ab}$ & 78 & 59.2 \\
\hline Check & 13.22 d & 0 & -103.5 & $26.06 \mathrm{e}$ & 0 & -27 \\
\hline
\end{tabular}

'Recommended rates during the first two applications.

-Double the recommended rates after the first two applications, except for permethrin, fenvalerate and B.t.

"Larvae per plant based on twice a week counts on 10 plants/plot. Values followed by the same letter do not differ significantly at $P=0.05$.

"; contro] = [1-(no. of larve treated/no. of larvale from the check)100].

$\therefore \%$ reduction $=[1-($ no. of larvae post treated/no. of larvae pretreated)100]. Negative signs indicate a tendency of the pest population to increase after each application. 
TABLE 2.-Experiment 1. Percentages of control of selected insecticides against Plutella xylostella (L.) on cabbage var. Market Prize 2 days and 6 days (one day before the application) after each application (Isabela, P. R.-Dec. 1982-Feb. 1983)

\begin{tabular}{|c|c|c|c|c|c|c|c|c|}
\hline \multirow{3}{*}{$\begin{array}{c}\text { Treatment } \\
\text { (rate/hectare) }\end{array}$} & \multicolumn{4}{|c|}{ Recommended rate ${ }^{1}$} & \multicolumn{4}{|c|}{ Double the recommended rate ${ }^{2}$} \\
\hline & \multicolumn{2}{|c|}{ 1st week } & \multicolumn{2}{|c|}{ 2nd week } & \multicolumn{2}{|c|}{ 3rd week } & \multicolumn{2}{|c|}{ 4th week } \\
\hline & 2 days $^{3}$ & 6 days & 2 days & 6 days & 2 days & 6 days & 2 days & 6 days \\
\hline Methamidophos 4E (1.17 L/ha) & 87 & 67 & 56 & 65 & 95 & 93 & 97 & 93 \\
\hline Methamidophos 4E (2.34 L/ha) & 99 & 94 & 93 & 94 & 100 & 97 & 97 & 93 \\
\hline Permethrin 2E $\quad$ (0.234 L/ha) & 100 & 99 & 100 & 100 & 100 & 100 & 100 & 100 \\
\hline Permethrin 2E & 96 & 100 & 100 & 100 & 100 & 100 & 100 & 100 \\
\hline Fenvalerate $2.4 \mathrm{E} \quad(0.351 \mathrm{~L} / \mathrm{ha})$ & 95 & 100 & 99 & 100 & 100 & 100 & 100 & 100 \\
\hline Diazinon AG500 & 61 & 43 & 27 & 46 & 46 & 48 & 79 & 59 \\
\hline Chlorpyrifos $4 \mathrm{EC} \quad(1.17 \mathrm{~L} / \mathrm{ha})$ & 67 & 61 & 53 & 69 & 57 & 53 & 97 & 92 \\
\hline Acephate $75 \mathrm{~S}$ & 90 & 77 & 77 & 92 & 97 & 99 & 99 & 98 \\
\hline Methomyl $90 \mathrm{~S}$ & 60 & 24 & 2 & -38 & 53 & 41 & 80 & 44 \\
\hline Dimethoate $2.67 \mathrm{EC}(1.17 \mathrm{~L} / \mathrm{ha})$ & 57 & 30 & 38 & 64 & 26 & 39 & 69 & 38 \\
\hline (1.2 kg/ha) & 83 & 80 & 87 & 78 & 90 & 94 & 93 & 81 \\
\hline Check & 0 & 0 & 0 & 0 & 0 & 0 & 0 & 0 \\
\hline
\end{tabular}

${ }^{1}$ Recommended rates during the first two applications.

${ }^{2}$ Double the recommended rates after the first two applications, except for permethrin, fenvalerate and B.t.

${ }^{3}$ The first application was made 30 days after transplanting. 
TABLE 3.-Experiment 1. Average number of marketable heads and non-marketable heads of cabbage var. Market Prize from plots treated. with insecticides for the control of Plutella xylostella (L.) (Isabela, P. R.: Dec. 1982-Feb. 1983)

\begin{tabular}{|c|c|c|c|c|c|}
\hline \multicolumn{2}{|c|}{$\begin{array}{l}\text { Treatment } \\
\text { (rate/hectare) }\end{array}$} & \multirow{2}{*}{$\frac{\begin{array}{c}\text { Marketable } \\
\text { heads' }\end{array}}{26.33 \mathrm{~b}}$} & \multirow{2}{*}{$\frac{\begin{array}{c}\text { Total weight } \\
(\mathrm{kg})\end{array}}{30.23 \mathrm{bc}}$} & \multirow{2}{*}{$\frac{\begin{array}{c}\text { Non-marketable } \\
\text { heads }\end{array}}{34.66 \mathrm{~b}}$} & \multirow{2}{*}{$\frac{\begin{array}{c}\text { Total weight } \\
(\mathrm{kg})\end{array}}{20.50 \mathrm{~cd}}$} \\
\hline Methamidophos $4 \mathrm{E}$ & (1.17 L/ha) & & & & \\
\hline Methamidophos $4 \mathrm{E}$ & (2.34 L/ha) & $52.00 \mathrm{a}$ & $60.47 a b$ & $7.00 \mathrm{a}$ & $2.66 \mathrm{ab}$ \\
\hline Permethrin $2 \mathrm{E}$ & (0.234 L/ha) & $55.00 \mathrm{a}$ & $56.73 \mathrm{ab}$ & $6.00 \mathrm{a}$ & $1.90 \mathrm{ab}$ \\
\hline Permethrin 2E & (0.468 L/ha) & $43.66 \mathrm{ab}$ & $52.80 \mathrm{ab}$ & $6.33 \mathrm{a}$ & $2.07 \mathrm{ab}$ \\
\hline Fenvalerate $2.4 \mathrm{E}$ & $(0.351 \mathrm{~L} / \mathrm{ha})$ & $52.00 \mathrm{a}$ & $62.90 \mathrm{a}$ & $5.00 \mathrm{a}$ & $1.20 \mathrm{a}$ \\
\hline Diazinon AG500 & (1.17 L/ha) & $00.57 \mathrm{c}$ & $00.43 d$ & $57.33 c$ & $46.03 \mathrm{ef}$ \\
\hline Chlorpyrifos $4 \mathrm{EC}$ & (1.17 LAha) & $24.00 \mathrm{~b}$ & $20.47 \mathrm{de}$ & $37.00 \mathrm{~b}$ & $17.63 \mathrm{bcd}$ \\
\hline Acephate $75 \mathrm{~S}$ & $(0.672 \mathrm{~kg} / \mathrm{ha})$ & $35.66 \mathrm{ab}$ & $39.63 \mathrm{abc}$ & $23.66 \mathrm{ab}$ & $11.57 \mathrm{abc}$ \\
\hline Methomyl 90S & $(0.6 \mathrm{~kg} / \mathrm{ha})$ & $00.00 \mathrm{c}$ & $00.00 \mathrm{~d}$ & $57.66 \mathrm{c}$ & $31.97 \mathrm{de}$ \\
\hline Dimethoate 2.67EC & (1.17 L/ha) & $1.66 c$ & $1.87 \mathrm{~d}$ & $56.33 \mathrm{c}$ & $44.07 \mathrm{ef}$ \\
\hline B.T. WP & $(1.2 \mathrm{~kg} / \mathrm{ha})$ & $40.33 \mathrm{ab}$ & $45.90 \mathrm{abc}$ & $18.00 \mathrm{ab}$ & $8.40 \mathrm{abc}$ \\
\hline Check & & $00.00 \mathrm{c}$ & $00.00 \mathrm{~d}$ & $58.66 \mathrm{c}$ & $48.07 \mathrm{f}$ \\
\hline
\end{tabular}

'Values followed by the same letter do not differ significantly at $\mathrm{P}=0.05$ (Duncan's Multiple Test). 
TABLE 4.-Experiment 2. Efficacy and yield data from cabbage var. Market Prize from plots treated with selected insecticides to control Plutella xylostella (L.) larvae (Isabela, P. R.; March 1983-May 198.3)

\begin{tabular}{|c|c|c|c|c|c|c|}
\hline & & \multicolumn{2}{|c|}{ Larvae per plant' } & \multirow[b]{2}{*}{$\begin{array}{l}\text { Percent } \\
\text { control }^{-3}\end{array}$} & \multicolumn{2}{|c|}{ Yield per plot" } \\
\hline \multicolumn{2}{|c|}{$\begin{array}{c}\text { Treatment } \\
\text { (rate/hectare) }\end{array}$} & 1st count" & 2nd count: & & $\begin{array}{l}\text { Marketable } \\
\text { heads }(\overline{\mathrm{X}})\end{array}$ & $\begin{array}{l}\text { Weight } \\
(\mathrm{kg})(\bar{X})\end{array}$ \\
\hline Methamidophos 4E & (2.34 L/ha) & 17.2 & 0.2 & 97.6 & $41.7 \mathrm{a}$ & $56.9 \mathrm{a}$ \\
\hline Permethrin 2E & (0.234 L/ha) & 1.2 & 0 & 100.0 & $51.7 \mathrm{a}$ & $60.8 \mathrm{a}$ \\
\hline Fenvalerate $2 \mathrm{E}$ & (0.351 L/ha) & 2.9 & 0 & 100.0 & $46.0 \mathrm{a}$ & $55.4 \mathrm{a}$ \\
\hline Diazinon AG500 & (2.34 L/ha) & 6.0 & 2.3 & 73.0 & $34.7 \mathrm{a}$ & $46.7 \mathrm{a}$ \\
\hline Chlorpyrifos $4 \mathrm{EC}$ & (2.34 L/ha) & 19.7 & 4.7 & 45.0 & $39.7 \mathrm{a}$ & $54.0 \mathrm{a}$ \\
\hline Acephate 75S & (1.34 kg/ha) & 10.7 & 0.8 & 91.0 & $40.0 \mathrm{a}$ & 55.5 a \\
\hline Methomyl $90 \mathrm{~S}$ & $(2.24 \mathrm{~kg} / \mathrm{ha})$ & 14.2 & 7.0 & 18.0 & $38.0 \mathrm{a}$ & $41.5 \mathrm{a}$ \\
\hline Dimethoate 2.67EC & (2.34 L/ha) & 4.9 & 8.1 & 4.7 & $39.3 a$ & $50.7 \mathrm{a}$ \\
\hline Endosulfan 50WP & $(0.56 \mathrm{~kg} / \mathrm{ha})$ & 18.7 & 6.8 & 20.0 & $43.7 \mathrm{a}$ & $50.9 a$ \\
\hline Endosulfan 50WP & $(1.12 \mathrm{~kg} / \mathrm{ha})$ & 15.5 & 6.3 & 26.0 & $45.7 \mathrm{a}$ & $58.4 \mathrm{a}$ \\
\hline Naled 8E & (1.17 L/ha) & 7.5 & 2.7 & 66.0 & $45.0 \mathrm{a}$ & $59.0 \mathrm{a}$ \\
\hline Naled $8 \mathrm{E}$ & (2.34 L/ha) & 17.1 & 3.5 & 59.0 & $41.3 a$ & $55.2 \mathrm{a}$ \\
\hline B.t. WP & (1.2 kg/ha) & 6.2 & 1.5 & 82.4 & $39.0 \mathrm{a}$ & $49.5 \mathrm{a}$ \\
\hline Check & & 16.8 & 8.5 & 0 & $40.7 \mathrm{a}$ & $51.4 \mathrm{a}$ \\
\hline
\end{tabular}

'Average number of larvae/plant based on larvae counted on 10 plants/plot.

"First count of larvae/plant made 31 days after transplanting; one day before the second application.

"Counts made 48 hours after the second and last application. Ten days later the cabbage plants were harvested.

$\checkmark \%$ control $=$ []-(no. of larvae treated/no. of larvae from the check) 100], based on the 2nd count only.

"Values followed by the same letter do not differ significantly at $\mathrm{P}=0.05$ with Duncan's Test. 
weekly samples of the number of larvae per plant were erratic. But 48 hours after the last application over $90 \%$ of control of the larvae was obtained with methamidophos $(2.34 \mathrm{~L} / \mathrm{ha})$, permethrin $(0.234 \mathrm{~L} / \mathrm{ha})$, fenvalerate $(0.351 \mathrm{~L} / \mathrm{ha})$, and acephate $(1.44 \mathrm{~kg} / \mathrm{acre})$. With B.t., $82.5 \%$ control was obtained. All the other insecticides tested were ineffective in controlling the larvae of $P$. xylostella (table 4).

Yield of marketable heads of the whole trial was fairly high. Marketable heads were obtained, but there were no significant differences among the treatments (table 4 ). The non-marketable yield constituted about $20 \%$ of the total harvest.

\section{Third trial}

There was a significant difference in the number of larvae per plant in the permethrin, fenvalerate, methamidophos, acephate and naled treatments (table 5). With fenvalerate, permethrin and acephate, over $90 \%$ control of the larvae was obtained. The counts made 48 hours and 6 days (= one day before the second application) after the applications showed that these chemicals maintained a high control of the larvae (table 6). Methamidophos, chlorpyrifos, and naled at the highest recommended rates controlled between 80 and $89 \%$ of the larvae. B.t. controlled $61 \%$ of the larvae. The insecticides diazinon, endosulfan, dimethoate and methomyl were ineffective even at the highest rates. The number of larvae populations when compared with the same plot, increased after the application of diazinon, chlorpyrifos, naled, endosulfan, dimethoate and methomyl. With methamidophos and B.t. the number of larvae increased or remained constant (table 7).

Significant differences in yield were obtained with acephate, methamidophos, chlorpyrifos, fenvalerate, B.t., naled and permethrin, whereas with acephate and fenvalerate $90 \%$ of the heads were marketable. With the other chemicals, practically no marketable heads were obtained (table 5).

\section{DISCUSSION}

In general, the insecticides that gave poor or no control were the ones already reported or expected to perform poorly. Methomyl, endosulfan, naled and diazinon are reported as not controlling effectively the larvae of $P$. xylostella $(2,4,5,20,23)$, whereas with methomyl generally there were the fewest marketable heads (23). With these chemicals, larval mortality above $50 \%$ could not be obtained with the rates recommended for cabbage. Many times plots treated with these chemicals did not differ from the check. In fact, it has been reported that diazinon and methomyl are already useless in China for controlling this pest (22). Bioassays demonstrated that by continuous selection of $P$. xylostella for 14 to 19 generations, resistance to diazinon and methomyl can be developed (14). Some strains of the pest in that region have already developed resistance to 
TABLE 5.-Experiment 3. Efficacy and yield data from cabbage var. Market Prize from plots treated with selected insecticides to control Plutella xylostella (L.) larvae (Isabela, P. R.; Dec. 1983-Feb. 1984)

\begin{tabular}{|c|c|c|c|c|c|c|}
\hline & & & \multirow{3}{*}{$\begin{array}{c}\begin{array}{c}\text { Percentage } \\
\text { of control }\end{array} \\
52\end{array}$} & \multicolumn{3}{|c|}{ Yield/plot and percentages } \\
\hline \multicolumn{2}{|c|}{$\begin{array}{l}\text { Treatment } \\
\text { (rate/hectare) }\end{array}$} & \multirow{2}{*}{$\frac{\text { Larvae/plant'.2 }}{8.58 c}$} & & \multirow{2}{*}{$\begin{array}{c}\begin{array}{l}\text { Weight/plant }(\mathrm{kg}) \\
\text { Marketable heads }\end{array} \\
0.298 \mathrm{c}\end{array}$} & \multirow{2}{*}{$\begin{array}{c}\begin{array}{c}\text { Marketable } \\
\text { heads }(\%)\end{array} \\
26.8 \mathrm{~b}\end{array}$} & \multirow{2}{*}{$\begin{array}{c}\begin{array}{c}\text { Non-marketable } \\
\text { heads }(\%)\end{array} \\
73.2\end{array}$} \\
\hline Diazinon AG500 & (2.34 L/ha) & & & & & \\
\hline Acephate 75S & $(1.344 \mathrm{~kg} / \mathrm{ha})$ & $1.23 \mathrm{ab}$ & 93 & $1.103 \mathrm{a}$ & $90.0 \mathrm{a}$ & 10.0 \\
\hline Methamidophos 4E & (2.34 L/ha) & $3.05 \mathrm{ab}$ & 83 & $1.120 \mathrm{a}$ & $76.2 \mathrm{a}$ & 23.8 \\
\hline Chlorpyrifos $4 \mathrm{EC}$ & (2.34 L/ha) & $3.23 \mathrm{~b}$ & 82 & $1.157 \mathrm{a}$ & $82.9 \mathrm{a}$ & 17.1 \\
\hline Fenvalerate $2 \mathrm{E}$ & $(0.351 \mathrm{~L} / \mathrm{ha})$ & $0.32 \mathrm{a}$ & 98 & $1.163 \mathrm{a}$ & $90.9 \mathrm{a}$ & 7.2 \\
\hline B.t. WP & $(1.2 \mathrm{~kg} / \mathrm{ha})$ & $7.06 \mathrm{c}$ & 61 & $1.033 \mathrm{ab}$ & $79.3 a$ & 20.7 \\
\hline Naled $8 \mathrm{E}$ & (2.34 L/ha) & $2.03 \mathrm{ab}$ & 89 & $1.037 \mathrm{ab}$ & $66.1 \mathrm{a}$ & 33.4 \\
\hline Permethrin 2E & (0.234 L/ha) & $0.30 \mathrm{a}$ & 98 & $1.050 \mathrm{ab}$ & $85.5 \mathrm{a}$ & 14.5 \\
\hline Endosulfan 50WP & (1.12 kf/ha) & $13.31 \mathrm{~d}$ & 26 & 0 & $0 \mathrm{c}$ & 100.0 \\
\hline Dimethoate 2.67EC & (2.34 L/ha) & $15.21 \mathrm{~d}$ & 15 & $\mathrm{c}$ & $\begin{array}{ll}0 & c\end{array}$ & 100.0 \\
\hline Methomyl 1.8L & (1.17 L/ha) & $12.62 \mathrm{~d}$ & 30 & $0.367 \mathrm{c}$ & $3.6 \mathrm{c}$ & 96.4 \\
\hline Check & & $17.95 \mathrm{f}$ & 0 & $0.467 b c$ & $0.9 \mathrm{c}$ & 99.1 \\
\hline
\end{tabular}

'Based on larvae/plants/plot.

${ }^{2}$ Values followed by the same letters do not differ significantly at $\mathrm{P}=0.05$ with Duncan's Multiple Test.

$3 \%$ control $=[1-($ no. of larvae treated-check/check) 100$]$. 
TABLE 6.-Experiment 3. Effectiveness of selected insecticides against Plutella xylostella (L.) larvae on cabbage var. Market Prize 2 days and 6 days (one day before the application) after the weekly applications (Isabela, P. R.; Dec. 1983-Feb. 1984)

\begin{tabular}{|c|c|c|c|c|c|c|c|c|c|c|c|c|}
\hline \multirow{3}{*}{\multicolumn{2}{|c|}{$\begin{array}{l}\text { Treatments } \\
\text { (rate/hectare) }\end{array}$}} & \multirow[b]{3}{*}{$1 \mathrm{dba}^{2}$} & \multicolumn{10}{|c|}{ Number of larvae per treatment } \\
\hline & & & \multicolumn{2}{|c|}{ Ist week } & \multicolumn{2}{|c|}{ 2nd week } & \multicolumn{2}{|c|}{3 rd week } & \multicolumn{2}{|c|}{ 4th week } & \multicolumn{2}{|c|}{5 th week } \\
\hline & & & 2 days & 6 days & 2 days & 6 days & 2 days & 6 days & 2 days & 6 days & 2 days & 6 days \\
\hline Diazinon AG500 & (2.34 L/ha) & 2.5 & 2.67 & 2.23 & 3.43 & 7.83 & 9.03 & 9.53 & 21.3 & 10.3 & 9.13 & 7.8 \\
\hline Acephate $75 \mathrm{~S}$ & $(1.344 \mathrm{~kg} / \mathrm{ha})$ & 2.5 & 1.47 & 0.73 & 0.97 & 1.93 & 0.73 & 0.53 & 0.7 & 1.2 & 0.30 & 1.3 \\
\hline Methamidophos 4E & (2.34 L/ha) & 2.5 & 0.20 & 1.10 & 2.57 & 4.83 & 1.00 & 1.83 & 3.0 & 3.8 & 6.10 & 3.6 \\
\hline Chlorpyrifos $4 \mathrm{EC}$ & (2.34 L/ha) & 2.5 & 2.93 & 2.43 & 1.33 & 2.23 & 2.13 & 2.47 & 8.8 & 5.2 & 0.57 & 1.8 \\
\hline Fenvalerate $2 \mathrm{E}$ & (0.351 L/ha) & 2.5 & 0.47 & 0.17 & 0.10 & 0.0 & 0.0 & 0.0 & 0.0 & 0.0 & 0.0 & \\
\hline B.t. WP & $(1.2 \mathrm{~kg} / \mathrm{ha})$ & 2.5 & 1.33 & 3.30 & 3.77 & 8.43 & 7.33 & 7.13 & 12.1 & 11.2 & 5.47 & 8.1 \\
\hline Naled 8E & $(2.34 \mathrm{~L} / \mathrm{ha})$ & 2.5 & 0.63 & 0.27 & 1.97 & 2.40 & 1.10 & 4.20 & 2.4 & 1.3 & 1.67 & 1.7 \\
\hline Permethrin 2E & (0.234 L/ha) & 2.5 & 0.17 & 0.10 & 0.17 & 0.67 & 0.0 & 0.0 & 0.0 & 0.0 & 0.0 & 0.0 \\
\hline Endosulfan 50WP & $(1.12 \mathrm{~kg} / \mathrm{ha})$ & 2.5 & 1.67 & 6.47 & 9.77 & 12.50 & 7.23 & 8.90 & 31.5 & 35.5 & 4.37 & 12.7 \\
\hline Dimethoate 2.67EC & $(2.34 \mathrm{~L} / \mathrm{ha})$ & 2.5 & 1.40 & 2.43 & 9.87 & 11.30 & 7.47 & 16.50 & 27.9 & 43.1 & 13.40 & 16.8 \\
\hline Methomyl 1.8L & $(1.17 \mathrm{~L} / \mathrm{ha})$ & 2.5 & 1.53 & 5.07 & 4.07 & 8.60 & 4.83 & 15.60 & 17.3 & 30.4 & 17.60 & 18.8 \\
\hline Check & & 2.5 & 4.57 & 6.33 & 12.40 & 11.10 & 9.40 & 17.90 & 40.9 & 30.5 & 17.80 & 26.1 \\
\hline
\end{tabular}

'Number of larvae/plant based on larvae found on 10 plants/plot.

${ }^{2} 1 \mathrm{dba}=1$ day before the first application; average number of larvae/plant, indicating that an application of insecticide was obligatory. 
TAsis: 7.-Experiment 3. Percentages of control and reduction of Plutella xylostella (L.) larvae by selected insecticides after each of fiue insecticide applications made on cabbage var. Market Prize (Isabela, P. R.; Dec. 1983-Feb. 198.4)

\begin{tabular}{|c|c|c|c|c|c|c|c|c|c|c|c|c|c|}
\hline \multirow{3}{*}{\multicolumn{2}{|c|}{$\begin{array}{l}\text { Treatment } \\
\text { (rate/hectare) }\end{array}$}} & \multicolumn{6}{|c|}{ Percent control' } & \multicolumn{6}{|c|}{ Percent reduction? } \\
\hline & & \multicolumn{6}{|c|}{ After each application } & \multicolumn{6}{|c|}{ After each application } \\
\hline & & 1 & 2 & 3 & 4 & 5 & $\bar{x}$ & 1 & 2 & 3 & 4 & 5 & $\bar{x}$ \\
\hline Diazinon AG500 & (2.34 L/ha) & 42 & 72 & 4 & 48 & 49 & 43.0 & -7.0 & -54.0 & -15.0 & -124.0 & -17.0 & -43.4 \\
\hline Acephate $75 \mathrm{~S}$ & (1.344 kg/ha) & 68 & 92 & 92 & 98 & 98 & 90.0 & 41.2 & -33.0 & 62.2 & -32.1 & 76.4 & 23.0 \\
\hline Methamidophos $4 \mathrm{E}$ & (2.34 L/ha) & 96 & 79 & 89 & 93 & 66 & 85.0 & 92.0 & -134.0 & 79.3 & -62.0 & -69.0 & -19.0 \\
\hline Chlorpyrifos $4 \mathrm{EC}$ & (2.34 L/ha) & 36 & 89 & 77 & 79 & 97 & 76.0 & -17.2 & 45.3 & 4.5 & -256.3 & 68.0 & -31.1 \\
\hline Fenvalerate $2 \mathrm{E}$ & (0.351 l/ha) & 90 & 99 & 100 & 100 & 100 & 98.0 & 81.2 & 41.2 & 100.0 & 100.0 & 100.0 & 84.5 \\
\hline B.t. WP & $(1.2 \mathrm{~kg} / \mathrm{ha})$ & 71 & 70 & 22 & 71 & 69 & 61.0 & 46.8 & -14.2 & 13.1 & -69.3 & 32.5 & 2.0 \\
\hline Naled $8 \mathrm{E}$ & (2.34 L/ha) & 86 & 84 & 88 & 94 & 91 & 89.0 & 74.8 & -630.0 & 54.2 & 42.9 & 1.8 & -91.3 \\
\hline Permethrin $2 \mathrm{E}$ & (0.234 L/ha) & 96 & 99 & 100 & 100 & 100 & 99.0 & 93.2 & -70.0 & 100.0 & 100.0 & 100.0 & 65.0 \\
\hline Endosulfan 50WP & $(1.12 \mathrm{~kg} / \mathrm{ha})$ & 64 & 21 & 23 & 23 & 75 & 41.2 & 33.2 & -51.0 & 42.2 & -254.0 & 65.0 & -33.0 \\
\hline Dimethoate 2.67EC & (2.34 L/ha) & 69 & 20 & 21 & 32 & 25 & 33.4 & 44.0 & -306.2 & 33.2 & -69.1 & 20.2 & -55.4 \\
\hline Methomyl 1.8L & (1.17 L/ha) & 67 & 67 & 49 & 58 & 1 & 48.4 & 38.8 & 19.7 & 43.8 & -110.9 & 6.4 & 20.0 \\
\hline Check & & - & - & - & - & - & - & -82.8 & -95.9 & 15.3 & -128.5 & 31.8 & -52.0 \\
\hline
\end{tabular}

$1 \%$ control $=[1-($ no. of larvae treated/no. of larvae from the check) 100$]$

$2 \%$ reduction $=[1-$ (no. of larvae post treated/no. of larvae pretreated) 100]. The percentages of each observation were obtained 2 days and 6 days ( $=$ one day before each application) after each application within the same plot without comparing it with the check. 
methamidophos, chlorpyrifos, and other insecticides $(14,16,18,21,22)$. In my first trial, control was improved in the plots where the rates were doubled. However, at this stage of the experiment the leaves were so badly damaged that it may not have been possible for the pest to maintain its high population on the plants. Thus, it is uncertain whether the insecticide at this increased rate was solely responsible for the reduction of the larvae population of $P$. xylostella. That may have been the case, for example, with methamidophos at the rate of $1.17 \mathrm{~L} / \mathrm{ha}$ when this rate was doubled after the first two applications.

Bacillus thuringiensis (B.t.) generally provided good control of the P. xylostella larvae with percentage control from 55 to $85 \%$ in previous studies (6). In some tests it was as effective as methamidophos (13) and was better than endosulfan (19). In some cases, yields from B.t.-treated plots were comparable to those treated with permethrin. This implies that the stage of the plant or the timing of the applictions may be very important. The problem with this biological insectide is that at least weekly (sometimes biweekly) applications are obligatory in order to maintain effective control. This amount can be expensive, but still this is an excellent alternative.

The best chemicals tested, i.e., those which prompted the highest yield of marketable heads, were the synthetic pyrethroids, permethrin and fenvalerate. These findings agree with past results from Taiwan and the United States $(5,15,16,17,20,23)$. However, in laboratory experiments in Taiwan (20), most of the field strains of the moth were shown to have already developed resistance to these synthetic pyrethroids. The effectiveness of these chemicals against the diamondback moth has already decreased considerably in the field (20). Despite the high levels of resistance detected, synthetic pyrethroids remain the most potent insecticides for this highly resistant diamondback moth population from the field (14).

With almost a total dependency on insecticides for controlling the insect pests in vegetables and the now popular and widespread use of synthetic pyrethroids in Puerto Rico P. xylostella will probably develop resistance to these new chemicals within a few years.

\section{LITERATURE CITED}

1. Abraham, E. M. and M. D. Dadmanaban, 1968. Bionomics and control of the diamondback moth, Plutella maculipennis Curtis. Indian J. Agric. Sci. 38 (3): 51319.

2. Andaloro, J. T., C. W. Hoy, K. B. Rose and A. M. Shelton, 1983. Evaluation of insecticide usage in the New York processing-cabbage pest management program. J. Econ. Entomol. 76 (5): 1121-24.

3. Armstrong, A. M. and C. Cruz, 1982. Insect population dynamics and economic threshold levels of crop insects important in Puerto Rico. Annual Progress Report, Project H-282. Agric. Exp. Stn., Univ. P. R., Dep. of Crop Protection, Mayagüez, P. R. (Unpublished data). 
4. Chalfant, R. B., 1978. Chemical control of insects of greens in Georgia. Res. Bull, 216, Coastal Plain Station, Tifton, Georgia.

5. — 1979. Action threshold for the cabbage caterpillar complex in Georgia. J. Ga. Entomol. Soc, 14 (4): 359-63.

6. Creighton, C. S. and T. L. McFadden, 1975. Cabbage caterpillars: Efficacy of chlordimeform and Bacillus thuringiensis in spray mixtures and comparative efficacy of several chemicals and B. thuringiensis formulations. J. Econ. Entomol. 68 (1): 57-60.

7. Cruz, C., 1973. Nuevos insecticidas que controlan el gusano del repollo. Adelantos Cientificos Núm. 2. Esta. Exp. Agric., Univ, P. R., Río Piedras, P. R.

8. —, 1973, 1974, 1975, 1981, Evaluation of selected insect control practices in crops of economic importance. Annual Progress Report, Project H-216. Agric. Exp. Stn., Univ. P. R., Dep. of Crop Protection, Mayagüez, P. R. (Unpublished data).

9. - 1980 and 1981. Insect population dynamics and economic threshold levels of crop insects important in Puerto Rico. Annual Progress Report, Project H-282. Agric. Exp. Stn., Univ. P. R. , Dep. of Crop Protection, Mayagüez, P. R. (Unpublished data).

10. — and A. L. González, 1979. Ibid.

11. Departamento de Agricultura, 1987. Oficina de Estadisticas Agricolas. ELA, Santurce, P. R., Personal Communication.

12. Eckenrode, E. J., J. T. Andaloro and A. M. Shelton, 1981. Suppression of lepidopterous larvae in commercial sauerkraut fields and research plots. J. Econ. Entomol. 74 (3): 276-79.

13. Krishnaiah, K., N. Jagan Mohan and V. G. Prasad, 1981. Efficacy of Bacillus thuringiensis Ber. for the control of lepidopterous pests of vegetable crops. Entomol. 6 (2): 87-93.

14. Liu, M. Y., Y. J. Tzeng and C. N. Sun, 1981. Diamondback moth resistance to several synthetic pyrethroids. J. Econ. Entomol. 74 (4): 393-96.

15. - - - 1982. Insecticide resistance in the diamondback moth. J. Econ. Entomol. 75 (1): 153-55.

16. Mohamad, R. B., Y. B. Ibrahim and C. W. Cheong, 1979. Field efficacy of several selected insecticides against the diamondback moth, Plutella xylostella (L.), on cabbage, Brassica oleracea var. capitata (L.), in the lowland of Malaysia, Perianika 2 (2): $84-8$.

17. Nichols, D. B. R. and N. French, 1983. Chemical control of diamondback moth on spring cabbage. Ann. Appl. Biol. 102: 14-5.

18. Noppun, V., T. Miyata and T. Saito, 1983. Susceptibility of four strains of the diamondback moth, Plutella xylostella L., against insecticides J. Pestic. Sci. 8 (4): 595-99.

19. Rahamona, N. and S. Jayaraj, 1978. Field efficacy of Bacillus thuringiensis and some other insecticides against pests of cabbage. Indian J. Agric. Sci. 48 (11): 672-75.

20. Schuster, D. J., R. B. Chalfant, W. H. Denton and R. B. Workman, 1978. Cooperative evaluation of chemical control of lepidopterous larvae on cabbage at four locations in Florida and Georgia. J. Ga. Entomol. Soc. 13 (4): 327-31.

21. Sudeeruddin, K. I., and P. F. Kok, 1978. Insecticide resistance in Plutella xylostella collected from the Cameron Highlands of Malaysia. FAO Plant Prot. Bull. 26 (2): 53-7.

22. Sun, C. N., H. Chi and H. T. Feng, 1978. Diamondback moth resistance to diazinon and methomyl in Taiwan. J. Econ. Entomol. 71 (3): 55l-54.

23. Workman, R. B., R. B. Chalfant and D. J. Schuster, 1980. Management of the cabbage looper and diamondback moth on cabbage by using two damage thresholds and five insecticide treatments. J. Econ. Entomol. 73 (6): 757-58. 